\title{
UJI PENGARUH TEPUNG AZOLLA (Anabaena azollae) DENGAN TAKARAN YANG BERBEDA PADA PAKAN TERHADAP PERTUMBUHAN DAN KELANGSUNGAN HIDUP IKAN NILA SRIKANDI (Oreochromis niloticus)
}

\author{
Sabbih Fatkhummubin ${ }^{1}$, Rahmad Jumadi $^{2}$, Sa'idah Luthfiyah $^{2}$ \\ ${ }^{1}$ Mahasiswa Program Studi Akuakultur, Fakultas Pertanian Universitas Muhammadiyah Gresik. \\ ${ }^{2}$ Dosen Program Studi Akuakultur, Fakultas Pertanian Universitas Muhammadiyah Gresik. \\ Email : immawansabbih95@gmail.com;+6287701274062
}

\begin{abstract}
This study was conducted to determine the effect of the provision of azolla flour into pellet feed to improve the performance of tilapia. This study used a complete randomized block (CRD) consisting of 4 treatments and 3 replications with doses, namely: (K - 100\% pellet feed), (A - 75\% + 25\% Azolla pellet), (B pellet $50 \%+50 \%$ Azolla $),(\mathrm{C}$ - pellet $25 \%+75 \%$ Azolla) main parameters include weight growth, survival and feed conversion ratio (FCR), feed utilization efficiency (EPP). While supporting parameters include temperature, $\mathrm{pH}, \mathrm{DO}$. Then the data obtained was processed dst and analyzed using excel, analysis of variance (ANOVA) with a confidence of $95 \%$ and continued using BNT test. If there was a significant effect on the treatment. The ANOVA test results showed that the administration of azolla flour on feed did not have a significant effect on absolute growth and daily growth rate, survival FCR, and efficiency of feed utilization (EPP) of tilapia $(\mathrm{p}<0.05)$, thus the results of the study could be concluded the addition of azolla flour to tilapia feed in this study did not have a significant effect, so there was no need to do further tests on $\mathrm{BNT}_{0.05}$ (Smallest Significant Difference). The results in this study on absolute growth control treatment amounted to 0.83 gram, specific growth rate of $0.69 \%$, FCR of 1.72 , survival (SR) of $53 \%$ while feed utilization efficiency (EPP) of $43.82 \%$ no one has a real influence.
\end{abstract}

Keywords: tilapia, azolla, fish feed, growth

\begin{abstract}
ABSTRAK
Penelitian ini dilakukan untuk mengetahui pengaruh dari pemberian tepung azolla ke dalam pakan pellet untuk meningkatkan performa ikan nila. Penelitian ini menggunakan rancangan acak lengkap (RAL) yang terdiri dari 4 perlakuan dan 3 ulangan dengan takaran yaitu: (K - pakan pellet 100\%), $(\mathrm{A}-$ pellet $75 \%+25 \%$ Azolla $),(\mathrm{B}$-pellet $50 \%+50 \%$ Azolla $),(\mathrm{C}-$ pellet $25 \%+$ 75\% Azolla) parameter utama meliputi pertumbuhan berat, kelangsungan hidup dan rasio konversi pakan (FCR), efisiensi pemanfaatan pakan (EPP). Sedangkan parameter penunjang meliputi suhu, $\mathrm{pH}$, DO. Data yang diperoleh kemudian diolah dan dianalisis dengan menggunakan excel, analisis sidik ragam (ANOVA) dengan kepercayaan $95 \%$ dan dilanjutkan dengan menggunakan uji BNT Jika terdapat perbedaan yang nyata pada perlakuan. Hasil uji Anova menunjukkan bahwa pemberian tepung azolla pada pakan tidak memberikan perbedaan yang nyata terhadap pertumbuhan mutlak dan laju pertumbuhan harian, FCR kelangsungan hidup, dan efisiensi pemenfaatan pakan (EPP) ikan nila $(\mathrm{p}<0,05)$,
\end{abstract}


Dengan demikian dapat disimpulkan hasil penelitian dengan penambahan tepung azolla pada pakan ikan nila dalam penelitian ini tidak ada yang memberikan perbedaan yang nyata maka tidak perlu dilakukan uji lanjut uji $\mathrm{BNT}_{0,05}$ (Beda nyata Terkecil). Hasil dalam penelitian ini pada perlakuan kontrol pertumbuhan mutlak sebesar 0,83 gram, laju pertumbuhan spesifik sebesar 0,69\%, FCR sebesar 1,72, kelangsungan hidup (SR) sebesar $53 \%$ sedangkan efisiensi pemanfaatan pakan (EPP) sebesar $43,82 \%$ tidak ada yang memberikan pengaruh yang nyata.

Kata kunci : ikan nila, azolla, pakan ikan, pertumbuhan

\section{PENDAHULUAN}

\section{Latar belakang}

Indonesia merupakan negara kaya akan sumber daya alam yang dapat di gali untuk kesejahteraan umat manusia. Salah satu sumberdaya alam yang berpotensi yaitu sektor perikanan. Ikan Nila (Oreochromis niloticus) merupakan jenis ikan air tawar yang banyak diminati oleh konsumen ikan air tawar. Usaha budidaya ikan nila sangat berkembang pesat di Indonesia. Saat ini permasalahan yang selalu muncul dikalangan pembudidaya adalah harga pakan ikan komersil yang tiap tahunnya cenderung meningkat, dan menjadi kendala dalam pengembangan kegiatan akuakultur kedepan sehingga perlu dicari alternatif pakan murah dengan kualitas relatif baik dan dapat tersedia sepanjang waktu.

Upaya yang dapat dilakukan untuk meningkatkan kandungan protein pakan komplit yaitu dengan penambahan tanaman azolla karena azolla tersebut memiliki kandungan protein yang cukup tinggi antara 24-30\% (Akrimi, 2001) dan masih kurang tereksploitasi manfaatnya ke dunia akuakultur.

Berdasarkan latar belakang dan perumusan masalah tersebut, maka tujuan yang ingin dicapai dari penelitian ini untuk melihat pengaruh penambahan tepung azolla kedalam pakan dengan takaran yang berbeda dengan menganalisis terhadap pertumbuhan dan kelangsunagan hidup ikan nila.

\section{TINJAUAN PUSTAKA}

Habitat ikan nila adalah perairan tawar, seperti sungai, danau, waduk, dan rawa-rawa, tetapi karena toleransinya yang luas terhadap salinitas (euryhaline) sehingga dapat pula hidup dengan baik di air payau (Ghufran, 2009). Ikan nila merupakan ikan yang dapat beradaptasi dengan baik. Spesies ini telah banyak ditemukan mampu hidup di segala macam air, mulai dari sungai, danau, dan saluran irigasi. Meskipun tergolong ikan air tawar, namun spesies ini dapat beradaptasi dengan kondisi perairan payau (Cholik, 2005). Ikan nila (Oreochromis niloticus) memakan makanan alami berupa plankton, perifiton dan tumbuh-tumbuhan lunak seperti hydrilla, ganggang sutera dan klekap. Pada masa pemeliharaan, ikan nila dapat diberi pakan buatan (pellet) yang mengandung protein antara 20-25\% (Ghufran, 2009).

Azolla merupakan jenis tumbuhan paku air yang tumbuh dengan baik di daerah tropis maupun sub-tropis. Azolla dapat tumbuh di kolam, saluran air, 
maupun area pertanaman padi sering disebut sebagai gulma air. Dengan tingginya nitrogen dalam azolla besar kemungkinan nitrogen ini dalam tubuh ikan dirubah menjadi protein sehingga protein inilah yang digunakan untuk pertumbuhan ikan. azolla juga dapat digunakan sebagai pakan sumber protein untuk ikan, itik, ayam, babi, sapi dan kuda. Karena tanaman ini memiliki kandungan protein yang cukup tinggi yaitu sebesar nilai nutrisi azolla mengandung kadar protein tinggi antara 24$30 \%$ (Akrimi, 2001) sehingga cocok kalau di gunakan sebagai campuran pakan sebagai protein nabati.

\section{METODE PENELITIAN}

\section{Waktu Dan Tempat}

Penelitian ini dilaksanakan di Laboratorium Akuakultur Universitas Muhammadiyah Gresik selama 35 hari dengan menggunakan ikan nila srikandi sebagai ikan uji dengan ukuran panjang $5-7 \mathrm{~cm}$ rerata bobot 5 g/ekor dari Kabupaten Lamongan. Pellet komersil dengan protein 12-14\% dan tepung azolla, Peralatan yang dibutuhkan dalam penelitian ini adalah 12 bak plastik dengan volume 16 liter diisi 15 ekor ikan uji. Peralatan pengambilan data yaitu timbangan digital, baskom plastik. Peralatan pengukur kualitas air yaitu $\mathrm{pH}$ meter, DO meter dan Thermometer.

Penelitian menggunakan pakan komersil dengan protein 12-14\%, yang ditambahkan dengan tepung azolla pada perlakuan (K : pellet 100\%), (A : pellet $75 \%$ + azolla 25\%), (B : pellet 50\% + azolla 50\%), (C : pellet $25 \%+$ azolla 75\%).Rancangan percobaan yang digunakan adalah Rancangan Acak Lengkap (RAL) data diolah dengan, analisis sidik ragam (ANOVA) untuk melihat ada tidaknya perbedaan yang nyata antara perlakuan. Selanjutnya hasil analisa sidik ragam dilanjutkan dengan uji lanjut (UJI BNT) jika terdapat perbedaan yang nyata.

\section{Parameter Penelitian}

\section{Pertumbuhan Bobot Mutlak}

Pertumbuhan bobot mutlak merupakan selisih antara pertumbuhan pada akhir penelitian dengan pertumbuhan pada awal penelitian. Menurut Effendie (1997), perhitungan pertumbuhan sebagai berikut:

$$
\mathrm{W}=\mathrm{Wt}-\mathrm{Wo}
$$

Keterangan:

$\mathrm{Wt}=$ Bobot rata-rata ikan uji pada akhir penelitian $(\mathrm{g})$

Wo $=$ Bobot rata-rata ikan uji pada awal penelitian $(\mathrm{g})$

\section{Laju Pertumbuhan Spesifik}

Laju pertumbuhan spesifik merupakan \% dari selisih berat akhir dan berat awal, dibagi dengan lamanya waktu pemeliharaan. Laju pertumbuhan spesifik adalah laju pertumbuhan harian .Rumus laju pertumbuhan harian Effendi (1979).

$$
\text { SGR }\left(\% / \text { hari }=\frac{\operatorname{In} W t-\operatorname{In} W_{0}}{T} \times 100 \%\right.
$$


Keterangan:

SGR : Spesific Growth Rate (\%/hari)

Wt : Bobot rata-rata ikan uji di akhir penelitian $(\mathrm{g})$

Wo : Bobot rata-rata ikan uji di awal penelitian $(\mathrm{g})$

$\mathrm{T} \quad$ : Waktu penelitian

\section{Kelangsungan Hidup}

Tingkat kelangsungan hidup atau Survival Rate (SR) adalah prosentase jumlah benih ikan yang masih hidup pada akhir penelitian dengan menghitung perbandingan dengan ikan di awal penelitian. Kelangsungan hidup ikan uji diperoleh dengan mengikuti rumus Effendie (1979) :

$\operatorname{SR}(\%)=\frac{N_{t}}{\mathrm{~N}_{0}} x 100$

Keterangan:

$\mathrm{SR}=$ Survival Rate $(\%)$

$\mathrm{Nt}=$ Jumlah ikan uji pada akhir penelitian (ekor)

No $=$ Jumlah ikan uji pada awal penelitian (ekor)

\section{HASIL DAN PEMBAHASAN}

\section{Pertumbuhan Bobot Mutlak}

Perlakuan yang memiliki pertumbuhan bobot mutlak lebih tinggi dari pada perlakuan yang lain adalah perlakuan K (kontrol) dan perlakuan paling rendah pada perlakuan A. Dengan nilai kisaran pertumbuhan bobot mutlak pada penelitian ini sebesar 0,38-0,97 gram, apabila disajikan dalam bentuk histogram dapat dilihat pada gambar 1 di bawah ini.

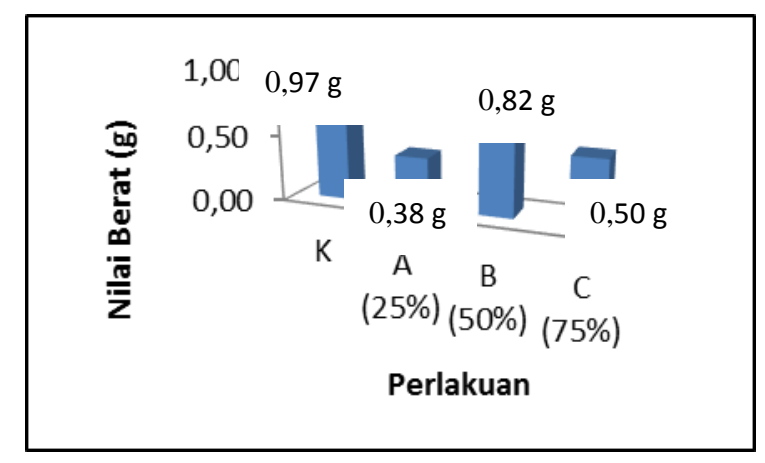

Gambar 1: Histogram Pertumbuhan Bobot Mutlak Ikan Nila (Oreochromis niloticus)

Tidak terlihatnya pengaruh yang nyata dari perlakuan yang diberikan dikarenakan oleh kualitas pakan yang kurang sesuai dengan kebutuhan ikan, karena jika pakan cocok dengan kebutuhan ikan dan kebiasaan makan terutama nutrisi maka semakin cepat pertumbuhannya, jika pakan tidak cocok maka ikan tersebut tidak dapat memanfaatkan pakan yang sudah diberikan akibatnya 
pertumbuhan akan terhambat begitulah yang terjadi pada perlakuan dengan penambahan tepung azolla selama penelitian sesuai dengan pernyataan Rukmana (1997) laju pertumbuhan suatu organisma ditentukan oleh kebutuhan pakan dan jenis pakan yang dikonsumsi harus cocok dengan kebiasaan makan, apabila tidak cocok maka organisme tersebut tidak dapat memanfaatkan pakan yang diberikan dengan baik akibatnya pertumbuhan akan terhambat atau relatif rendah.

Hal ini disebabkan oleh rendahnya kandungan protein pada pakan yang terkandung dalam pakan uji yang memiliki protein kurang dari 20\% sehingga menyebabkan pertumbuhan ikan lebih lambat, sesuai peryataan Kordi (1997) ikan nila dapat tumbuh lebih cepat hanya dengan pakan yang mengandung protein sebanyak $20-25 \%$. selain itu, pemberian pakan dengan nilai protein yang kurang dari 20\% menyebabkan pembentukan jaringan baru tidak banyak terbentuk, karena tidak sesuai dengan jumlah kebutuhan ikan nila (20-25\%). Marzuki, dkk (2012) menyebutkan bahwa penggunaan pakan dengan kandungan protein yang sesuai kebutuhan dan jumlah optimum akan menyebabkan pembentukan jaringan baru sehingga laju pertumbuhan meningkat. Hal ini didukung pernyataan Heptarina dkk (2010) yang membuktikan bahwa ketersediaan asam amino pakan untuk disimpan menjadi asam amino tubuh atau protein tubuh semakin besar dengan penambahan protein dalam pakan.

\section{Laju Pertumbuhan Spesifik}

Pada parameter laju pertumbuhan spesifik menunjukkan bahwa kontrol (tanpa penambahan tepung azolla) lebih besar daripada perlakuan (dengan penambahan tepung azolla) dengan kisaran nilai $0,34-0,69 \% /$ hari, apabila di sajikan dalam bentuk histogram dapat dilihat pada Gambar 2 dibawah ini.

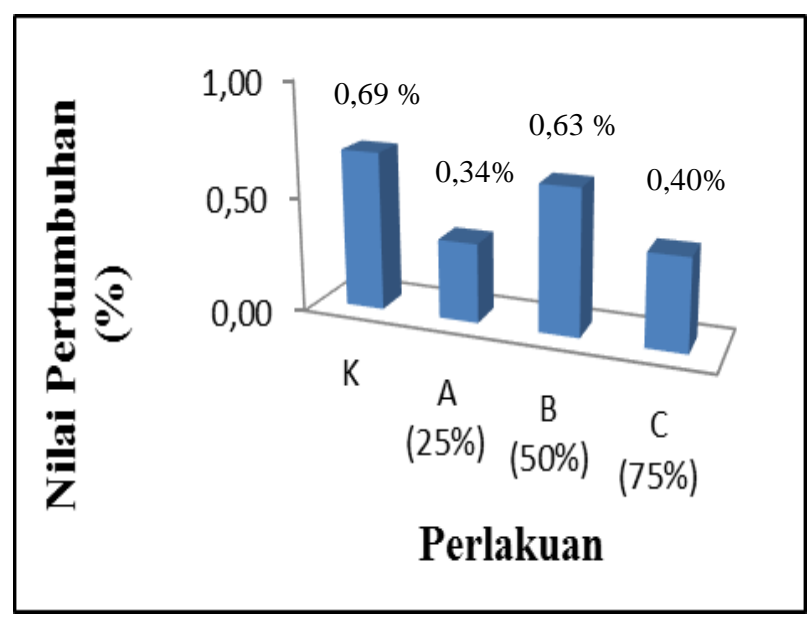

Gambar 2: Histogram Laju Pertumbuhan Spesifik Ikan Nila (Oreochromis niloticus) 
Perlakuan K yang memiliki laju pertumbuhan lebih besar dari pada yang lain dan perlakuan paling rendah di peroleh pada perlakuan A. Nilai kisaran laju pertumbuhan spesifik pada penelitian ini sebesar 0,34 - 0,69\%/harinya. Perlakuan A memberikan laju pertumbuhan yang rendah karena kekurangan protein dalam pakan dapat menyebabkan terhambatnya pertumbuhan, diikuti oleh kehilangan bobot tubuh ikan. Pemakaian protein dari jaringan tubuh untuk memelihara fungsi vital sesuai dengan pendapat Rachmawati Samidjan (2014), ikan dapat tumbuh dengan baik jika asupan nutriennya tercukupi, terutama kebutuhan protein. Almatsier (2001), karbohidrat yang cukup akan mencegah penggunaan protein untuk energi, sehingga protein yang ada dapat lebih dimanfaatkan untuk pertumbuhan. Menurut Mokoginta et al. (1995) menyatakan bahwa pertumbuhan ikan paling besar dipengaruhi oleh keseimbangan protein dan energi dalam pakan, kekurangan dan kelebihan energi pakan dapat menurunkan pertumbuhan ikan.

Adapun pada perlakuan pakan hanya digunakan hanya cukup untuk kebutuhan energi, sedangkan pakan yang dikonsumsi pertama-tama akan digunakan untuk memelihara tubuh dan mengganti sel-sel yang rusak, selebihnya digunakan untuk pertumbuhan. Hal ini sesuai dengan pernyataan Effendie (1997); Samidjan (2013) menyatakan bahwa pertumbuhan terjadi apabila terdapat kelebihan energi hasil metabolisme setelah digunakan untuk pemeliharaan tubuh dan aktivitas. Secara keseluruhan pertumbuhan harian pada perlakuan pakan ikan nila mengalami peningkatan jika pakan bisa direspon untuk proses metabolisme dan pertumbuhan pada saat pemberian pakan jika pakan tidak bisa direspon oleh ikan untuk proses metabolisme dan pertumbuhan maka pertumbuhan ikan akan lambat tidak memberikan pengaruh yang nyata.

Hal ini sesuai dengan pernyataan Fujaya (2004), bahwa ikan akan mengkonsumsi pakan hingga akan memenuhi kebutuhan energinya,tidak terlihatnya pengaruh yang nyata dari perlakuan yang diberikan dapat pula dikarenakan oleh serat kasar yang terkandung dalam pakan. Serat kasar yang lebih dari $8 \%$ tidak bisa dimanfaatkan oleh ikan sehingga pertumbuhan ikan akan lambat dikarenakan serat kasar akan menyebabkan penyerapan nutrisi penting dalam pakan berkurang. hal tersebut yang terjadi pada perlakuan yang penambahan tepung azolla yang mengandung serat kasar yang tinggi yang menyebabkan penyerapan nutrisi yang penting berkurang sehingga pertumbuhan lambat di bandingkan perlakuan kontrol. Menurut NRC (1993), kadar serat kasar yang dapat ditoleransi oleh ikan nila dalam pakan adalah $8 \%$, serat kasar yang tinggi dalam pakan akan menurunkan pertumbuhan ikan yang menyebabkan berkurangnya daya cerna pakan. 


\section{Kelangsungan Hidup}

Nilai kisaran kelangsungan hidup pada penelitian ini sebesar $44-53 \%$, dan apa bila disajikan dalam bentuk hstogram dapat dilihat pada Gambar 3 di bawah ini.

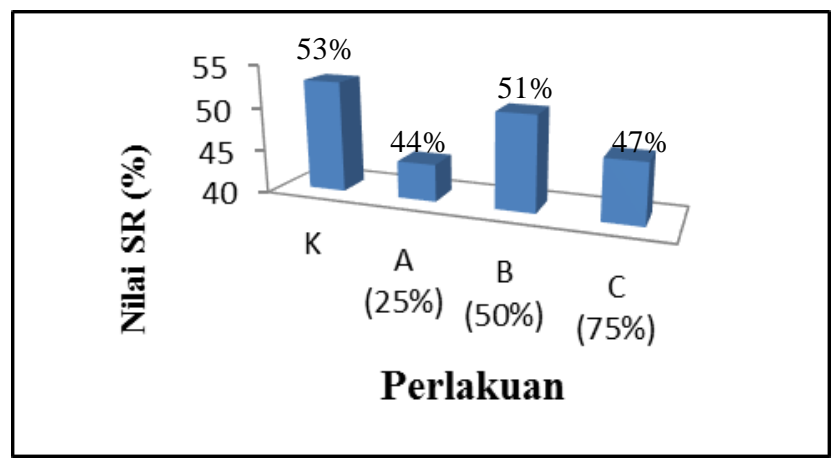

Gambar 3: Histogram Kelangsungan Hidup Ikan Nila (Oreochromis niloticus)

Kelangsungan hidup pada ikan nila diduga dipengaruhi oleh beberapa faktor kualitas pakan dan kualitas air jika pakan bisa termanfaatkan dengan baik serta didukung kualitas air yang baik juga maka kelangsungan hidup ikan tinggi. Ronald, (2002) bahwa pakan ikan mempunyai peranan penting bagi pertumbuhan dan tingkat kelangsungan hidup ikan. Pakan yang memiliki kandungan nutrisi yang tidak memenuhi kebutuhan hidup ikan diduga dapat mengakibatkan kondisi fisiologi ikan menurun, ketersedian pakan dan kesesuaian pakan dalam lingkungan tempat hidup ikan merupakan faktor penting yang dapat mempengaruhi kelangsungan hidup. Fungsi pakan tidak hanya untuk pertumbuhan dan energi tetapi juga untuk mempertahankan hidup, Pakan berfungsi sebagai sumber energi bagi ikan yang digunakan untuk mempertahankan hidupnya, pertumbuhan, reproduksi menurut Bagjaraya, (1999).

Menurut Irianto (2005), pemberian pakan dengan kandungan nutrien yang cukup dan seimbang akan berpengaruh terhadap kesehatan dan kelangsungan hidup ikan. Dan menurut Murjani (2011) menyatakan bahwa kelangsungan hidup ikan sangat bergantung pada daya adaptasi ikan terhadap makanan dan lingkungan, status kesehatan ikan, padat tebar, dan kualitas air yang cukup mendukung pertumbuhan rendahnya tingkat kelangsungan hidup selama penelitian tidak terlihatnya pengaruh yang nyata atas perlakuan yang diberikan.

Kordi, (2009) menyatakan bahwa rendahnya kelangsungan hidup suatu biota budidaya dipengaruhi beberapa faktor salah satunya nutrisi pakan yang tidak sesuai. Selama penelitian berlangsung terjadi banyak kematian pada perlakuan di bandingkan kontrol kemungkinan disebabkan oleh kandungan serat kasar yang tinggi 23,06 \% pada tepung azolla yang mempengaruhi daya cerna ikan nila sehingga nutrisi untuk keberlangsungan hidup ikan tidak bisa di manfaatkan secara baik oleh ikan. kandungan serat kasar pada pakan ikan nila tidak lebih dari 
$8 \%$. bahwa tingkat kelangsungan $\geq 50 \%$ tergolong baik, kelangsungan hidup 30 $50 \%$ sedang dan kurang dari 30\% tidak baik, kandungan serat kasar yang tinggi pada tepung azolla yang menyebabkan menurunnya kecernaan pakan dan dapat mempengaruhi tingkat kelangsungan hidup pada ikan pakan yang seharusnya di gunakan dalam proses kelangsungan hidup ikan tidak bisa termanfaatkan dengan baik terdapat kandungan serat kasar yang tinggi pada pakan perlakuan yang mengakibatkan terganggunya proses pencernaan pada pakan sehingga akan memepengaruhi poses kelangsungan hidup pada ikan selama penelitian berlangsung, kandungan serat kasar tidak boleh lebih dari $8 \%$ dalam pakan ikan (Kordi 2014).

\section{UCAPAN TERIMAKASIH} kepada:

Pada kesempatan ini penulis mengucapkan terima kasih yang tulus

1. Ibu Ir. Endah Sri Redjeki, M.P., M.Phil. selaku Dekan Fakultas Pertanian dan

2. selaku Pembimbing Pertama ProgramUniversitas Muhammadiyah Gresik.

3. Dr. Andi Rahmad Rahim, S.Pi, M.Si selaku Ketua Program Studi Akuakultur Universitas Muhammadiyah Gresik.

4. Ir.Rahmad Jumadi, M.Kes selaku Dosen Pembimbing Pertama yang selalu memberikan pengarahan dan dukungan kepada penulis.

5. Sa'idah Luthfiyah, S.Pi M.P.selaku Dosen Pembimbing Kedua yang selalu memberi semangat dan arahan yang baik.

6. Dosen Prodi Akuakultur, Fakultas Pertanian, Universitas Muhammadiyah Gresik yang telah memberikan ilmu selama perkuliahan.

7. Teman - teman angkatan 2014 dan seluruh mahasiswa Program Studi Akuakultur yang telah banyak membantu saya.

\section{KESIMPULAN DAN SARAN \\ Kesimpulan}

Penambahan tepung azolla (Annabaena azollae) dengan takaran yang berbeda didalam pakan komersil tidak menunjukan perbedaan yang nyata terhadap tiap parameter yang diujikan dengan besaran nilai tiap parameter uji berkisar antara 0,38 - 0,97 gram pada pertumbuhan bobot mutlak, 0,34-0, 69 $\% /$ harinya pada laju pertumbuhan spesifik, 44 - 53\% pada kelangsungan hidup ikan nila.

\section{Saran}

Perlu adanya penelitian lebih lanjut mengenai pemanfaatan tepung azolla yang sudah terkomposting kedalam pakan buatan mengingat hijauan yang telah terkomposting sudah terurai kedalam bentuk lebih sederhana sehingga diharapkan nutrisinya dapat memberikan pengaruh yang nyata terhadap ikan uji. 


\section{DAFTAR PUSTAKA}

Akrimi. 2001. Pemberian Azolla sebagai Pakan Tambahan Ikan Nila Merah.Buletin Teknik Pertanian. 6(2):63-65.

Almatsier, S. 2001. Prisnsip Dasar Ilmu Gizi. Gramedia Pustaka Utama, Jakarta.

Anonim. 2006. Bahan Alternatif Pakan dari Hasil Samping Industri Pangan. Departemen kelautan dan perikanan Republik Indonesia : BBAT Jambi DITJEN Perikanan Budidaya. hal. 5-7.

Bagjaraya, A. 1999. Pengaruh Subtitusi Tepung Ikan Dengan Tepung Bulu Ayam Dalam Pakan Buatan Terhadap Laju Sintasan Dan Pertumbuhan Benih Ikan Nila GIFT. Universitas Padjadjaran

Effendie, M.I. 1979. Metoda Biologi Perikanan. Yayasan Dewi Sri. Bogor. 112 hlm.

Effendie, M.I 1997. Biologi Perikanan. Yayasan pustaka Nusatama. Yogyakarta $163 \mathrm{~h}$.

Fujaya, Y. 2004. Fisiologi Ikan : Dasar Pengembangan Teknik Perikanan. Rineka Cipta. Jakarta. hal. 131.

Heptarina, D., M. A. Supriyadi, I. Mokoginta dan D. Yaniharto. 2010. Pengaruh Pemberian Pakan dengan Kadar Protein Berbeda Terhadap Pertumbuhan Yuwana Udang Putih Litopenaeus vannamei. Prosiding Forum Inovasi Teknologi Akua-kultur. 6 hal.

Irianto, A. 2005. Patologi Ikan Teleostei. Gajah Mada University press Yogyakarta

Kordi K, M. G.H. 1997 a. Budidaya Ikan Nila. Penerbit Dahara Prize, Semarang 2009 b. Budidaya Ikan Nila. Dahara Prize. Semaran . 2014 c. Budidaya Ikan Nila. Dahara Prize. Semaran

Marzuqi M. 2015. Pengaruh Kadar Karboidrat Dalam Pakan Terhadap Pertumbuhan, Efisiensi Pakan, dan Aktivitas Enzim Amilase Pada Ikan Bandeng (Chanos chanos Forsskal). Tesis. Program Studi Biologi. Universitas Udayana. Denpasar.

Mokoginta I, MA Suprayudi dan M Setiawati. 1995. Kebutuhan Optimum Protein dan Energi Pakan Benih Ikan Gurame (Osphronemus gouramy) Lac Jurnal Penelitian Perikanan Indonesia 1 (3), 82- 95.

Murjani, A. 2011. Budidaya beberapa varietas ikan sepat rawa (Trichogaster trichopterus Pall) dengan pemberian pakan komersial. Jurnal Fish Scientiae.1(2): 214-233.

Ronald WH., 2002. Fish Nutrition. United States Of America: Academic Press An Imprint Of Elsevier Scence.

Rosmawati. 2005. Hidrolisis Pakan Buatan oleh Enzim Pepsin dan Pankreatin untuk Meningkatkan Daya Cerna dan Pertumbuhan Benih Ikan Gurami (Osphronemus gouramy). [Tesis]. Sekolah Pasca Sarjana. Institut Pertanian Bogor, Bogor, 80 hlm.

Rachmawati, D. dan I. Samidjan. 2014. Penambahan Fitase dalam Pakan Buatan sebagai Upaya Peningkatan Kecernaan, Laju Pertumbuhan Spesifik dan Kelulushidupan Benih Ikan Nila (Oreochromis niloticus). J. Saintek Perikanan. 10 (1) : 48-55.

Rukmana, R. 1997. Ikan Nila, Budidaya dan Prospek Agribisnis. Yogyakarta : Kanisius.

Yulianto, T. 2006. Pembenihan Ikan Nila. Satker PBIAT Janti. Klaten 